\title{
Applying Chosen Teaching Methods in Technical Education
}

\author{
http://dx.doi.org/10.3991/ijep.v4i4.3855 \\ H. Noga \\ Pedagogical University, Cracow, Poland
}

\begin{abstract}
Education, also the technical one, is supposed to prepare students for adult life, not only by providing them with ready-made knowledge, but first of all by equipping students with an ability to learn, gather and select information. Active methods influence students' senses, allowing for a better understanding and remembering the subject matter.
\end{abstract}

The study shows some didactic methods used in technical education. The attention has been aid to inventive, exploratory, and inventive-exploratory methods.

Index Terms - activation, education, methods, technology.

\section{INTRODUCTION}

One of the most effective methods which leads to acquiring specific skills is learning through action, called also learning through experience. Applying suitable active methods, a teacher can create an "active group" from a given class. Thanks to such a group the class is not divided into active and passive students. They can get to know each other better, as well as build up their mutual trust and openness. The author of this paper and Maria Vargová [8] claim that each student in a separate and individual way has a possibility to solve a problem and make a decision. Using active methods breaks the routine and boredom of the school reality. It has been described, among others, by Elżbieta Sałata [10], Maria Vargová [14] and Aleksandra Knych [5]. Introducing any novelties or games increases students' engagement in a lesson. Active methods can also be used in teaching students of higher educational levels, e.g. at the faculties connected with occupational safety and health, which has been signalled by Jana Depešová [2].

Technology is a specific subject. It requires a huge activity from students. That is why active methods are most suitable to teach it [6].

\section{INVENTIVE METHODS}

\section{A. $A R Z W$ (ARIZ) Method}

This method was created by Genrich Altshuller, a Russian scientist, who devoted all his research to find a way of behavior leading to an invention. He claims that from the very beginning one should concentrate on the best solution, thus making it an ideal solution.

ARIZ is this method abbreviation, which in Polish translates as "theory of inventive problem solving."

An ideal solution is not a simple thing. It entails a lot of difficulties which influence a creator's potential error. Among the difficulties is a discrepancy which makes one of the technical subject parameters improve while simultaneously another one worsens [7].
On the basis of his experiences and inventions analysis Altshuller created three tools leading to an ideal solution:

- technical objects features,

- the table for technical discrepancies elimination,

- operations for technical discrepancies elimination.

A lesson conducted with the use of the above method might have a following plan:

a) presenting the method to the students, relating to a given problem and identifying a problematic task,

b) to specify the task students use some didactic tools, e.g. literature; then they analyze the task and formulate it in a simple way,

c) this is an analytical stage in which students reach the final effect and establish the presented object characteristic features, as well as an operative stage used to eliminate appearing technical discrepancies.

Summing up, an optimal solution is connected with eliminating the above mentioned discrepancies.

\section{EXPLORATORY METHODS}

\section{A. The "Black Box" Method}

This method is widely used in technical education. A black box is just an external cover of a technical device whose interior is to be discovered by students.

A lesson conducted with the use of the above method might consist of three stages:

1. Specifying a problem and establishing the rules of work.

2. Students, being equipped with unidentified systems, the elements of a "black box", observe the changes in its output caused by the changes in its input and try to establish the function of a given object. Having observed and analyzed all the elements, a name is assigned to the object and its parameters are defined.

3. Presenting the results of the analyses and verifying the adopted solutions by the box opening.

This method gives very good effects in identifying the electronic elements and systems.

\section{B. The "Super Trash" Method}

The following method is based on searching by the students in their surroundings such technical devices which are highly useless or badly constructed.

At the beginning of a lesson the teacher refers to the role of technology in human life. He/she shortly presents the advantages of the appliances as well as their disadvantages still present despite a great development of the 
civilization. The teacher gives examples of technical objects and technological processes which do not fulfill their basic functions, such as a torch which does not emit light, a pen which does not write, etc. Next the students present a structure that can be named a "super dud" and then they work on how to solve the problem. In the final stage they present their solutions, discuss them with the teacher and choose the device which is the faultiest.

\section{The Puzzle Method}

This method requires good organization and preparation of some teaching aids.

The students are divided into smaller groups consisting of the same number of people, if possible. Each student in a group gets a different subtopic to work on, so the number of subtopics depends on the number of students in a given group.

A lesson conducted with this method might look like that:

1. In the introductory stage of the lesson teacher shortly presents students with the subject of the meeting and then divides them into groups.

2. All the students get supplementary materials and additionally, within each group, everybody gets a different subject to work on.

3. Students individually acquaint themselves with a given topic.

4. "Expert" groups meet in a consultation session (students appointed with the same topic exchange their opinions and solve the common problems together).

5. Then, in the initial groups, they share their knowledge with other members of the team.

6. The final stage of the lesson is when the teacher checks the knowledge or the skills acquired by the students. Students may also exchange their queries. Everybody's work should be marked.

The puzzle method, even if quite demanding and timeconsuming, gives the students a feeling of a natural, unconstrained atmosphere.

\section{INVENTIVE-EXPLORATORY METHODS}

\section{A. Discussion in Technical Education}

It is an extremely important method as far as teaching technology is concerned. It is based on a discussion between a teacher and students, or just among students. Its vital features are diverse opinions of the participants who should be intellectually mature. A participant should skillfully formulate the subject, clearly present their own arguments and suitably interpret the opponent's arguments.

Panel discussion is used when the number of participants is big or when there is a big discrepancy between the students' levels of knowledge. The course of the discussion of this kind is presented by A. Marszałek in the way shown in Table I.

The best results in teaching technology are acquired by using plenary discussion to solving problems connected with the technology development and environment protection. In such a case in the panel there are students prepared earlier from a given technology section.

The round table discussion is characterized by a huge freedom and equality of all its participants. The teacher just organizes it. A technology lesson conducted with the use of the above method consists of three stages, shown in Table II.

The them in the middle of round table is mostly applied in loving the technical problems.

TABLE I.

The Course OF a PANEl Discussion [7]

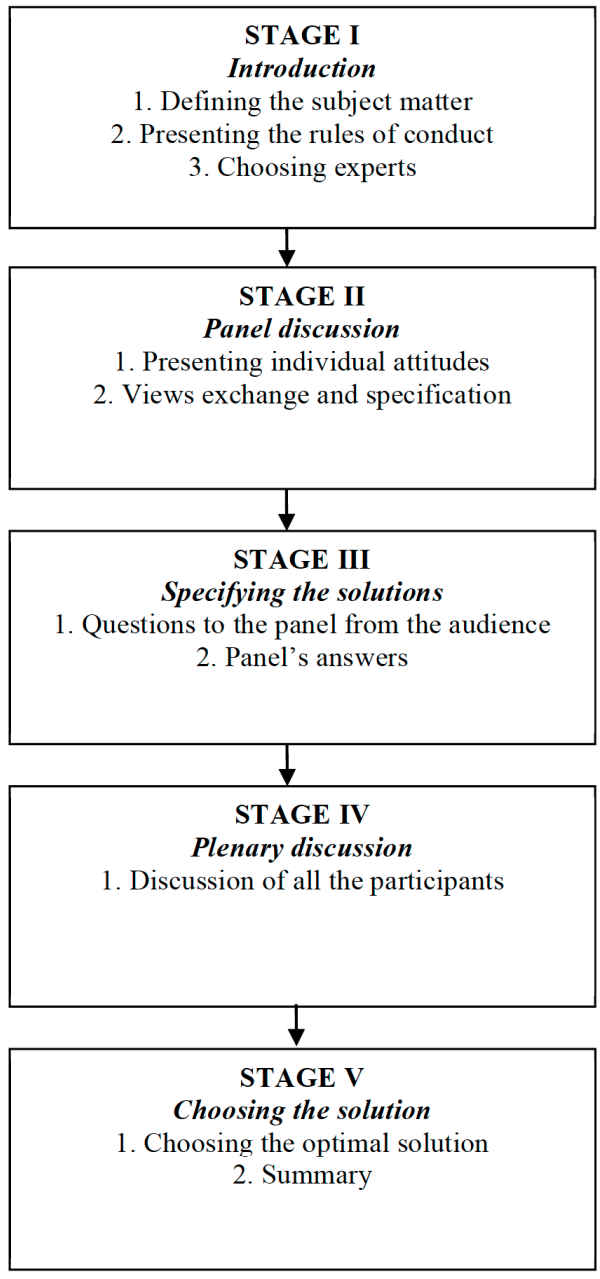

TABLE II

The Course of A ROUND TABLE Discussion [7]

\begin{tabular}{|c|}
\hline $\begin{array}{l}\text { STAGE I } \\
\text { Introduction } \\
\text { 1. Defining the subject matter } \\
\text { 2. Presenting the rules of conduct }\end{array}$ \\
\hline 1 \\
\hline $\begin{array}{l}\text { STAGE II } \\
\text { Discussion } \\
\text { 1. Presenting individual attitudes } \\
\text { 2. Views exchange and specification } \\
\text { 3. Assuming a given solution }\end{array}$ \\
\hline 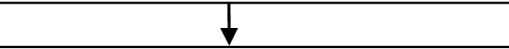 \\
\hline $\begin{array}{c}\text { STAGE III } \\
\text { Solution realization } \\
\text { 1. Working out a schedule for the solution } \\
\text { realization } \\
\text { 2. Summary }\end{array}$ \\
\hline
\end{tabular}




\section{B. Modelling}

It is a method belonging to a group of designing constructive methods. It is based on conducting research of an object which is just an image of a real one.

In technological education this method is especially important because it is exactly on the basis of models that various complex structures are made in order to avoid mistakes later. In this method one can apply computer programs which are used to modify and measure simulated mechanical and electronic structures. There are no problems getting such kinds of software nowadays. The only drawback is the fact that experiments are carried out on models, not on real objects.

\section{Delphi Method}

This method was born in ancient Greece, in the city of Delphi. In those times it was based on asking questions, after which all ideas or forecasts were revised in the light of other opinions or the reality.

In technical education this method is particularly applied to inventive tasks or to forecasting the changes in science and technology. Nowadays students provide ideas anonymously and then they choose the best one.

The course of a lesson conducted with the use of the Delphi method may look like that:

- tage one: defining and analyzing the problem, establishing the rules of conduct and the criteria for its judgment,

- tage two: teacher asks students additional questions, directing them to the way of solving a given problem and then students, using various sources, individually write suggested solutions on pieces of paper,

- tage three: teacher makes a list in which all of the students' suggestions are placed, next each student receives such a list, modifies it and, if needed, adds more solutions,

- tage four: teacher presents all the ideas gathered from the beginning of the meeting which are then further analyzed and judged.

\section{Fishbone Strategy} fects.

This method is known as a scheme of causes and ef-

The course of a lesson:

- On a poster or board teacher draws an outline resembling a fish skeleton. On the tip of it he/she writes a problem.

- Using the brainstorming method students enumerate the main factors which led to the problem and write them next to the bold lines, i.e. "big fish bones".

- Teacher divides students into a number of groups corresponding with the number of big bones. Each group gets one main factor and in a set time tries to discover its causes.

- Group representatives add further detailed causes next to the smaller, horizontal bones.

- Students choose the most important detailed factors.

- Students draw conclusions and solve the problem.

\section{E. Graffiti}

This method develops creative thinking in a fun atmosphere. It helps students solve problems creatively and gives them an opportunity to share their own ideas.

The course of the above method looks as following:

- teacher divides the class into groups,

- he/she sets the time limit,

- each group gets a poster with a sentence (the beginning of a story),

- students continue the story,

- after the set time limit they hand the poster over to the next group,

- the poster circulates clockwise among the groups,

- the task ends when the poster reaches the first group,

- students hang the posters and read the whole story.

\section{F. The 635 Method}

This method is a modification of the brainstorming. Having learnt about the problem, the participants are asked to write down three ideas. After a few (e.g. 5) minutes, neighboring students exchange their notes in order to solve the problem or modify the obtained ideas. After the next few minutes the participants again exchange ideas and add their own ones. This process lasts until the sheet of paper with ideas, gradually corrected and improved, has been in the hands of all the students. In the following stage the best solutions are chosen and presented. With six students taking part, the session lasts until each piece of paper with three ideas on it is completed by the five remaining participants (hence the name of the method).

The advantages of the following method include:

- each of the initial ideas is systematically completed and further developed,

- the creators can have the authorship of their ideas documented and they do not hesitate to reveal them,

- there is a document of the sessions and neither a chair person nor a secretary has to be appointed" [7].

Most of the active methods use various techniques: memory, imagination development and creativity ones. Teachers willingly use the already tried methods as well as frequently create their own ones. Thanks to that they develop their own imagination and students' creativity. As Beata Uchto writes in her article, "... such work gives the students enormous satisfaction. This enables the teacher to enter various new roles: of a creator, participant, observer, counselor and guide. The roles frequently change and the teacher becomes a background person, while the students come to the foreground" [11].

Active methods make use of potential abilities in each of the students. They prepare them for a correct reception of the reality through all the senses, develop the ability to learn, teach proper communication, team work, dealing with various situations. They also help in better knowing themselves and getting rid of inhibitions. They teach joint responsibility and taking actions for the benefit of the class or school [15]. 


\section{SUMMARY}

Reorganized school should prepare students for new tasks which need to be faced in a modern economy. Together with a socioeconomic development, the demands for school grow as well. Because of that some schools make students' technical preparation their main educational goal. A fast and dynamic development of technology that we witness nowadays requires from teachers a didactic preparation adequate to the contemporary school and students' possibilities.

Teacher's job should be to direct students' cognitive activities and to shape in students such features as perceptiveness, precision, honesty, independence, ability to assess themselves and gather information.

Each teacher has his or her own way of working with students. This form of a teacher-student collaboration is a specific method of education which creates a space for students' activity enabling a comprehensive development of their personalities. The topic of a lesson should be clear and understandable for students. That is why it should be carefully considered which method will allow for the best presentation of a given subject matter.

General technical education on all the levels gives an opportunity to "pass in its course a particular knowledge potential of a man, citizen and worker. It is obvious, that it should be the basis of vocational training" [9]. Technical education is more and more present in our lives both as individuals and as a society. What follows is the fact that we are to a great extent addicted to technology. That is why a high standard of technical education in our schools is extremely important. Its mere essence is evolving to adjust to the conditions and standards of civilization.

However, what seems to be the most crucial is not to discourage a student from learning. On the contrary, school should be seen as interesting and stimulating. Teachers should look for effective teaching methods, use various didactic tools and in this way improve the quality of teaching. A technology lesson might in an exceptional way serve the development of interests and creative abilities, stimulate activity and build on students' willingness to act.

\section{REFERENCES}

[1] Depešová J., K novému študijnému programu pre I. stupeň ZŠ. In: Zborník. Vplyv technickej výchovy na rozvoj osobnosti žiaka. Nitra: PF UKF, 2000, ISBN 80-8050-459-8.
[2] Depešová J., Odborná príprava bezpečnostných technikov, [w:] V.Stoffova, K. Jaracz, H. Noga, Didmattech XXIV. Problemy edukacji nauczycieli, Kraków 2011

[3] Depešová J., Ludové remeslá a tradície v štúdiu technickej výchovy. In: Zborník Modernizace výuky v technicky orientovaný choborech a prědmětech. Olomouc: PF UP, 2000. s. $277-278$. ISBN 80-244-0107-X.

[4] Jakowicka M., Uździcki K.(red.), Edukacja ogólnotechniczna na przełomie XX i XXI wieku, Oficyna Wydawnicza „Impuls”, Kraków 2003.

[5] Knych A., Twórczość techniczna uczniów, [w:] M. Havelka, M. Chráska, M. Klement, C. Serafin (red.), Trendy ve vzděláváni 2013, Pedagogickié Faculty UP v Olomouci, Olomouc 2013, ISBN 978-80-86768-52-6, s. 90-93.

[6] Kozík T., Depešová J., Technická výchova v Slovenskej republike $v$ kontente vzdelávania v krajinách Európskej únie, Nitra 2007.

[7] Marszałek A., Metody aktywizujace w nauczaniu i uczeniu się techniki, Ośrodek Doskonalenia Pedagogicznego, Rzeszów - Tarnobrzeg 1999.

[8] Noga H., Vargová M., Poziom postaw twórczych a uczestnictwo w technologii informacyjnej na przykladzie gier komputerowych, Annales Universitatis Paedagogicae, Studia Technica VI.

[9] Nowacki T., Aktywne metody w kształceniu, Centralny Ośrodek Doskonalenia Nauczycieli, Warszawa 1999.

[10] Sałata E., Nauczanie problemowe w edukacji technicznej, Radom 2010.

[11] Uchto B., Aktywne metody w nauczaniu, „Edukacja i Dialog” 2005, no. 6

[12] Vargová M., Aktuálne otázky technického vzdelávania na I. stupni $Z \breve{S}$. In: Modernizácia výučby v technicky orientovaných oboroch a predmetoch. Zborník. 1. vyd. Olomouc: PF UP, 1999, ISBN 80244-0051-0.

[13] Vargová M., Skúsenosti z overovania metamorfózneho modelu didaktiky. In: Inovačné trendy vovýchove a vzdelávaní. Zborník. 1. vyd. Brezno: Hogeschool Helicon, Zeist, Holandsko, PF UKF Centrum projektu Zmena, 2000. ISBN 80-8050-322-2.

[14] Vargová M., Pomšár Z., Praktické činnosti s materiami, Nitra 2012, pp. 5-7.

[15] Wieczór E., Metody aktywne - szansa dla edukacji, „Edukacja i Dialog" 2001, no. 9-10.

\section{AUTHOR}

H. Noga - professor of Pedagogical University in Cracow and the director of the Didactics in Technical Education Unit in the Institute of Technology UP. Henryk Noga is the author of around 20 books and over 200 articles on didactics in technical education. Main interests: didactics of technical subjects, multimedia in education, adult education, family studies (e-mail: senoga@cyf-kr.edu.pl).

Submitted 10 May 2014. PÜublished as resubmitted by the author 05 October 2014. 